\title{
KUALITAS YOGHURT YANG DIBUAT DENGAN KULTUR DUA (Lactobacillus bulgaricus DAN Streptococcus thermophilus) DAN TIGA BAKTERI (Lactobacillus bulgaricus, Streptococcus thermophilus DAN Lactobacillus acidophilus)
}

Saadah D. Rachman ${ }^{\mathrm{a}}$, Sadiah Djajasoepena ${ }^{\mathrm{a}}$, Dian S. Kamara ${ }^{\mathrm{a}}$, Idar Idar $^{\mathrm{b}}$, Roni Sutrisna ${ }^{\mathrm{a}}$, Agus Safari $^{\mathrm{a}}$, O. Suprijana ${ }^{\mathrm{a}}, \&$ Safri Ishmayana ${ }^{\mathrm{a}, *}$

${ }^{a}$ Departemen Kimia, Fakultas Matematika dan Ilmu Pengetahuan Alam, Universitas Padjadjaran, Jln. Raya Bandung-Sumedang km. 21, Jatinangor, Sumedang, Jawa Barat 45363

${ }^{\mathrm{b}}$ Sekolah Tinggi Farmasi Bandung, Jln. Soekarno - Hatta No.754, Bandung, Jawa Barat 40617

*Alamat Korespondensi: ishmayana@unpad.ac.id

Abstrak: Yoghurt merupakan produk susu terfermentasi yang dibuat dengan menambahkan kultur bakteri asam laktat (BAL) ke dalam susu. Kultur BAL yang ditambahkan dapat berupa kultur bakteri tunggal ataupun campuran. Pada umumnya, kultur campuran yang biasa digunakan untuk membuat yoghurt adalah campuran antara Lactobacilus bulgaricus (Lb) dan Streptococcus thermophilus (St). Namun berdasarkan beberapa penelitian kedua bakteri ini tidak bertahan lama pada saluran pencernaan. Oleh karena itu pada penelitian ini dilakukan penambahan Lactobacillus acidophilus (La) untuk memperbaiki sifat probiotik dari produk yoghurt. Pada pembuatan kultur starter, kultur tunggal bakteri ditumbuhkan pada media susu skim $10 \%$. Kemudian susu sapi hasil pasteurisasi diinokulasi dengan kultur starter dengan perbandingan kultur yang berbeda-beda yaitu 1:1, 1:4 dan 4:1 (Lb:St) untuk kultur dua bakteri serta 1:1:1, 1:4:1 dan 4:1:1 (Lb:St:La) untuk kultur tiga bakteri. Susu yang telah diinokulasi kemudian diinkubasi pada suhu $40^{\circ} \mathrm{C}$ selama $12 \mathrm{jam}$. Analisis terhadap produk yoghurt meliputi pengukuran $\mathrm{pH}$, kadar laktosa, kadar asam laktat dan kadar protein. Hasil analisis menunjukkan bahwa penambahan $L$. acidophilus cenderung memberikan efek penghambatan pembentukan asam laktat, seperti ditunjukkan oleh $\mathrm{pH}$ yang lebih tinggi, kadar asam laktat yang lebih rendah serta kadar laktosa sisa yang lebih tinggi pada yoghurt yang menggunakan kultur tiga bakteri.

Kata kunci: Yoghurt, Lactobacillus bulgaricus, Streptococcus thermophilus, Lactobacillus acidophilus

Abstract: Yoghurt is fermented milk product that is made by addition of lactic acid bacteria (LAB) into milk. Culture of LAB added to the milk can be single or mixed culture. Lactobacillus bulgaricus and Streptocuccus thermophilus are commonly used as mixed culture in yoghurt production. However, according of some reports, both of the bacteria can not survive in the gastrointestinal tract. Therefore, in the present study we add Lactobacillus acidophilus to improve probiotic properties of the yoghurt. To prepare starter culture, single cultures of the bacteria were grown in 10\% (w/v) skimmed milk. Pasteurized cow milk were then inoculated using starter culture with different culture starter ratio, which are 1:1, 1:4 and 4:1 (Lb:St) for two bacteria culture and 1:1:1, 1:4:1 and 4:1:1 (Lb:St:La) for three bacteria culture. The inoculated milk was then incubated at $40^{\circ} \mathrm{C}$ for 12 hours. The yoghurt product was analyzed for its $\mathrm{pH}$, lactose content, lactic acid content and

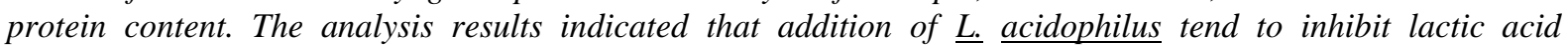
formation as shown by higher $\mathrm{pH}$, lower lactic acid content and higher remaining lactose in yoghurt with three bacteria culture.

Keywords: Yoghurt, Lactobacillus bulgaricus, Streptococcus thermophilus, Lactobacillus acidophilus

\section{PENDAHULUAN}

Yoghurt merupakan produk susu yang difermentasi menggunakan bakteri asam laktat (BAL). Pada proses fermentasi yoghurt dapat digunakan kultur tunggal ataupun campuran dari BAL. L. bulgaricus dan S. thermophilus merupakan bakteri yang umum digunakan sebagai kultur starter pada proses fermentasi susu menjadi yoghurt (ElAbbassy \& Sitohy, 1993). Ketika digunakan sebagai kultur campuran, kedua bakteri ini bersimbiosis mutualisme, dimana L. bulgaricus dilaporkan menghasilkan asam amino dan peptida pendek yang menstimulasi pertumbuhan $S$. thermophilus. Sedangkan $S$. thermophilus menghasilkan asam format yang menunjang pertumbuhan L. bulgaricus
(El-Abbassy \& Sitohy, 1993; Rajagopal \& Sandine, 1990).

L. bulgaricus dan $S$. thermophilus pada umumnya dilaporkan tidak dapat bertahan hidup pada saluran pencernaan (Conway et al. 1987). Oleh karena itu, kedua bakteri ini dianggap sebagai agen probiotik yang kurang baik, dan hanya dianggap sebagai kultur starter. Namun penelitian yang lebih baru melaporkan bahwa kedua bakteri ini ternyata dapat bertahan hidup di saluran pencernaan (Mater et al., 2005). Selain itu, Lick et al. (2001) dan Elli et al. (2006) juga menemukan bahwa L. bulgaricus dan $S$. thermophilus dapat bertahan hidup setelah melewati saluran pencernaan.

Lactobacillus acidophilus dan Bifidobacterium spp. merupakan BAL yang dilaporkan memiliki 
ketahanan yang lebih baik dalam saluran pencernaan manusia (Gomez \& Malcata 1999). Oleh karena itu penelitian mengenai penambahan kedua bakteri ini pada kultur campuran menjadi salah satu topik yang menarik karena adanya interaksi antara bakteribakteri tersebut dengan bakteri kultur starter (Vinderola et al. 2002) yang dapat mempengaruhi kualitas produk yang diinginkan (Gardini et al. 1999).

Pada penelitian ini, L. acidophilus ditambahkan ke dalam kultur campuran $L$. bulgaricus dan $S$. thermophilus. Kualitas yoghurt yang dihasilkan ditentukan dengan menentukan beberapa parameter uji yaitu $\mathrm{pH}$, kadar laktosa, kadar asam laktat dan protein.

\section{BAHAN DAN METODE} Alat

Alat yang digunakan pada penelitian ini adalah inkubator, spektrofotometer Jenway 6350, sentrifugasi, laminar flow cabinet (Forma Scientific), mikroskop (Nikon), pH meter (Mettler Toledo MP220), termometer, dan alat-alat gelas yang umum digunakan di laboratorium

\section{Bahan yang digunakan}

Bahan yang digunakan antara lain adalah susu skim, susu murni, air suling, natrium hidroksida, asam sulfat, fenolftalein, glukosa, laktosa, bovine serum albumin, tembaga sulfat pentahidrat, nutrient broth, pereaksi Folin-Ciocalteu, pereaksi fosfomolibdat, kultur bakteri $L$. bulgaricus, $S$. thermophilus dan L. acidophilus.

\section{Pembuatan kultur starter tunggal}

Ke dalam $5 \mathrm{~mL}$ susu skim hasil pasteurisasi dalam tiga botol vial steril dimasukkan masingmasing satu ose L. bulgaricus pada botol vial pertama, S. thermophilis pada botol vial kedua dan $L$. acidophilus pada botol vial ketiga. Ketiga botol ini diinkubasi pada suhu $37^{\circ} \mathrm{C}$ selama 24 jam, selanjutnya susu hasil fermentasi tersebut dipindahkan ke dalam $50 \mathrm{~mL}$ susu murni hasil pasteurisasi pada suhu $85^{\circ} \mathrm{C}$ selama 15 menit, kemudian diinkubasi pada suhu $37^{\circ} \mathrm{C}$ selama 24 jam. Susu hasil fermentasi merupakan kultur yang siap digunakan. Jika tidak langsung digunakan dapat disimpan pada suhu $4{ }^{\circ} \mathrm{C}$.

\section{Fermentasi susu}

Sebelum fermentasi, susu murni dipasteurisasi terlebih dahulu pada suhu $85^{\circ} \mathrm{C}$ selama 15 menit, kemudian sebanyak $50 \mathrm{~mL}$ dimasukkan ke dalam enam labu Erlenmeyer $250 \mathrm{~mL}$ steril. Setelah itu ke dalam labu Erlemeyer yang berbeda dimasukkan kultur starter dengan perbandingan volume kultur tunggal 1:1, 1:4 dan 4:1 untuk kultur dua bakteri ( $L$. bulgaricus: $S$. thermophilus) dan 1:1:1, 1:4:1 dan 1:1:4 untuk kultur tiga bakteri (L. bulgaricus: $S$. thermophilus: L. acidophilus). Campuran kemudian diinkubasi pada suhu $40^{\circ} \mathrm{C}$. Sampel diambil setelah
12 jam. Hasil fermentasi ini kemudian dianalisis untuk nilai $\mathrm{pH}$, kadar asam total, kadar protein dan kadar laktosa.

\section{Pengukuran pH}

Sampel produk yoghurt yang dihasilkan diukur $\mathrm{pH}$-nya dengan menggunakan $\mathrm{pH}$ meter.

\section{Penentuan kadar asam laktat}

Sebanyak $10 \mathrm{~mL}$ yoghurt dimasukkan ke dalam labu Erlenemeyer dan ditambahkan 2-3 tetes larutan fenolftalein $1 \%$ sebagai indikator. Buret diisi dengan larutan natrium hidroksida $0,1 \mathrm{~N}$. Larutan yoghurt kemudian dititrasi dengan menggunakan larutan $\mathrm{NaOH}$ sampai terjadi perubahan warna menjadi kemerahan.

\section{Penentuan kadar protein}

Sebanyak $0,1 \mathrm{~mL}$ larutan standar BSA $(0,00$; 0,$05 ; 0,10 ; 0,20 ; 0,30 ; 0,40$ dan $0,50 \mathrm{mg} / \mathrm{mL}$ ) atau sampel yang akan ditentukan kadar proteinnya dimasukkan ke dalam tabung reaksi. Kemudian ditambahkan sebanyak $5 \mathrm{~mL}$ pereaksi Lowry C (50 $\mathrm{mL} 2 \%$ natrium karbonat dalam $0,1 \mathrm{~N}$ natrium hidroksida : $1 \mathrm{~mL} 0,5 \%$ tembaga sulfat pentahidrat dalam $1 \%$ natrium tartrat) dan didiamkan selama 10 menit. Sebanyak 0,5 mL larutan Folin-Ciocalteu kemudian ditambahkan, dikocok dan didiamkan selama 30 menit. Serapan diukur pada panjang gelombang $750 \mathrm{~nm}$ dengan menggunakan spektrofotometer.

\section{Penentuan kadar laktosa}

Sebanyak $1 \mathrm{~mL}$ sampel dimasukkan ke dalam labu ukur $100 \mathrm{~mL}$, lalu ditambahkan dengan $2 \mathrm{~mL}$ larutan natrium tungstat dan $2 \mathrm{~mL}$ asam sulfat $0,3 \mathrm{M}$ sambil dikocok perlahan. Kemudian ditambahkan air suling sampai tanda batas dan dibiarkan selama 5 menit lalu disentrifugasi. Supernatan yang diperoleh diambil sebanyak $1 \mathrm{~mL}$ kemudian dimasukkan ke dalam tabung reaksi dan ditambah dengan $1 \mathrm{~mL}$ air suling. Selanjutnya ke dalam tabung reaksi tersebut ditambahkan pereaksi tembaga alkalis dan dipanaskan pada penangas air selama 8 menit lalu didinginkan dan ditambah dengan $4 \mathrm{~mL}$ larutan fosfomolibdat sambil dikocok. Setelah itu, larutan dimasukkan ke dalam labu ukur $25 \mathrm{~mL}$ dan diencerkan dengan larutan fosfomolibdat encer (1:4). Serapan kemudian diukur pada panjang gelombang $630 \mathrm{~nm}$ dengan menggunakan spektrofotometer.

Larutan standar laktosa dibuat dengan menimbang $1 \mathrm{~g}$ laktosa lalu dilarutkan dalam labu ukur $100 \mathrm{~mL}$ dengan larutan asam benzoat $0,2 \%$. Sebanyak $3 \mathrm{~mL}$ larutan kemudian diambil dan dimasukkan ke dalam labu ukur $100 \mathrm{~mL}$ dan diencerkan dengan menggunakan larutan asam benzoat $0,2 \%$. Larutan standar tersebut kemudian diambil sebanyak $1 \mathrm{~mL}$ dan dimasukkan ke dalam tabung reaksi kemudian ditambahkan air suling. Langkah kerja berikutnya sama dengan langkah kerja yang dijelaskan sebelumnya. Untuk blanko 
digunakan air suling sebanyak $2 \mathrm{~mL}$ dan ditambahkan dengan reagen yang sama.

\section{HASIL DAN PEMBAHASAN pH produk yoghurt}

Hasil pengukuran $\mathrm{pH}$ produk yoghurt ditunjukkan pada Tabel 1. Menurut Food Standards Australia New Zealand (2014) pH yoghurt yang baik memiliki nilai maksimum 4,5. Berdasarkan hasil yang ditunjukkan pada Tabel 1, produk yoghurt yang menggunakan kultur dua bakteri memenuhi standar yang ditetapkan oleh Food Standards Australia New Zealand. Sedangkan yoghurt yang dibuat dengan tiga kultur bakteri memiliki $\mathrm{pH}$ sedikit di atas standar. Meskipun demikian, nilai $\mathrm{pH}$ produk yoghurt dengan tiga kultur bakteri masih mendekati nilai standar di sekitar $\mathrm{pH} \sim 4,5$.

Nilai $\mathrm{pH}$ kultur tiga bakteri yang lebih tinggi kemungkinan besar terjadi karena penurunan kemampuan bakteri untuk menghasilkan produk asam.

Tabel 1. Nilai $\mathrm{pH}$ yoghurt dengan variasi perbandingan antara kultur starter campuran dua bakteri (L. bulgaricus:S. thermophilus) dan tiga bakteri (L. bulgaricus:S. thermophilus:L. acidophilus) dan waktu inkubasi 12 jam.

\begin{tabular}{cc}
\hline $\begin{array}{c}\text { Perbandingan kultur starter } \\
\text { (Lb:St) atau (Lb:St:La) }\end{array}$ & $\mathrm{pH}$ \\
\hline $1: 1$ & 4,48 \\
$1: 4$ & 4,49 \\
$4: 1$ & 4,41 \\
$1: 1: 1$ & 4,56 \\
$1: 4: 1$ & 4,55 \\
$4: 1: 1$ & 4.52 \\
\hline
\end{tabular}

\section{Kadar laktosa}

Kadar laktosa ditentukan dengan metode penentuan gula pereduksi sesuai yang dijelaskan oleh Somogyi (1951) dan Nelson (1944). Penentuan kadar laktosa dilakukan untuk mengetahui kemampuan kultur bakteri untuk mengonversi laktosa menjadi asam laktat. Kadar laktosa susu sapi sebelum fermentasi adalah sebesar 7,94\% (b/v) (Safari dkk., 2016), sedangkan kadar laktosa setelah proses fermentasi disajikan pada Tabel 2.

Tabel 2. Kadar laktosa yoghurt dengan variasi perbandingan kultur starter campuran dua bakteri ( $L$. bulgaricus : $S$. thermophilus) dan tiga bakteri ( $L$. bulgaricus : S. thermophilus : L. acidophilus) dan waktu inkubasi $12 \mathrm{jam}$.

\begin{tabular}{cc}
\hline $\begin{array}{c}\text { Perbandingan kultur starter } \\
(\text { Lb:St }) \text { atau }(\text { Lb:St:La })\end{array}$ & $\begin{array}{c}\text { Kadar Laktosa } \\
(\% \mathrm{~b} / \mathrm{v})\end{array}$ \\
\hline $1: 1$ & 2,86 \\
$1: 4$ & 2,60 \\
$4: 1$ & 2,25 \\
$1: 1: 1$ & 3,84 \\
$1: 4: 1$ & 4,14 \\
$4: 1: 1$ & 3,94 \\
\hline
\end{tabular}

Hasil pengukuran kadar laktosa menunjukkan bahwa yoghurt yang dibuat dengan kultur dua bakteri mengonsumsi lebih banyak laktosa dibandingkan kultur tiga bakteri. Hal ini juga mengindikasikan adanya efek inhibisi dari penambahan L. acidophilus terhadap kemampuan kultur bakteri dalam mengonsumsi laktosa untuk diubah menjadi asam laktat.

\section{Kadar asam laktat}

Menurut SNI 2981:2009, kadar asam laktat yoghurt yang baik adalah sebesar 0,5-2,0\%. Kadar asam laktat yoghurt hasil penelitian ini ditampilkan pada Tabel 3 .

Tabel 3. Kadar asam laktat yoghurt dengan variasi perbandingan kultur starter campuran dua bakteri ( $L$. bulgaricus : $S$. thermophilus) dan tiga bakteri ( $L$. bulgaricus : S. thermophilus : L. acidophilus) dan waktu inkubasi 12 jam.

\begin{tabular}{cc}
\hline $\begin{array}{c}\text { Perbandingan kultur starter } \\
(\text { Lb:St) atau }(\text { Lb:St:La })\end{array}$ & $\begin{array}{c}\text { Kadar asam laktat } \\
(\% \mathrm{~b} / \mathrm{v})\end{array}$ \\
\hline $1: 1$ & 1,21 \\
$1: 4$ & 1,15 \\
$4: 1$ & 1,27 \\
$1: 1: 1$ & 1,14 \\
$1: 4: 1$ & 1,11 \\
$4: 1: 1$ & 1,15 \\
\hline
\end{tabular}

Hasil analisis kadar asam laktat yang ditunjukkan pada Tabel 3 menunjukkan bahwa semua produk yoghurt pada penelitian ini memenuhi syarat SNI. Hasil analisis kadar asam laktat sesuai dengan data $\mathrm{pH}$ dan data kadar laktosa, dimana sampelsampel yoghurt yang menggunakan tiga kultur bakteri cenderung memiliki kadar asam laktat yang lebih sedikit, yang berarti mengonsumsi laktosa lebih sedikit dan memiliki nilai $\mathrm{pH}$ yang lebih tinggi.

Fenomena ini dapat terjadi karena adanya interaksi antara bakteri-bakteri yang digunakan dalam kultur starter. Vinderola et al. (2002) mengungkapkan bahwa L. acidophilus dapat menghambat pertumbuhan L. bulgaricus, sedangkan $S$. thermophilus tidak menunjukkan interaksi yang berarti dengan L. acidophilus. Hal ini menunjukkan adanya inhibisi pertumbuhan L. bulgaricus yang pada akhirnya akan dapat menghambat konsumsi laktosa untuk diubah menjadi asam laktat, yang berakibat memberikan nilai $\mathrm{pH}$ yang relatif lebih tinggi.

\section{Kadar Protein}

Kadar protein sampel yoghurt yang dibuat dengan kultur dua dan tiga bakteri ditunjukkan pada Tabel 4. Menurut SNI 2981:2009 kadar protein minimal yang harus ada pada yoghurt adalah sebesar 2,7\% sedangkan menurut Food Standards Australia New Zealand (FSANZ, 2014) adalah 3\%. Kedua lembaga ini menggunakan metode Kjeldahl untuk menentukan kadar protein, sehingga keseluruhan protein yang ada pada sampel ikut ditentukan. 
Tabel 4. Kadar protein yoghurt dengan variasi perbandingan kultur starter campuran dua bakteri ( $L$. bulgaricus : $S$. thermophilus) dan tiga bakteri ( $L$. bulgaricus : S. thermophilus : L. acidophilus) dan waktu inkubasi 12 jam.

\begin{tabular}{cc}
\hline $\begin{array}{c}\text { Perbandingan kultur starter } \\
(\text { Lb:St) atau }(\text { Lb:St:La })\end{array}$ & $\begin{array}{c}\text { Kadar Protein } \\
(\% \mathrm{~b} / \mathrm{v})\end{array}$ \\
\hline $1: 1$ & 0,26 \\
$1: 4$ & 0,24 \\
$4: 1$ & 0,23 \\
$1: 1: 1$ & 0,30 \\
$1: 4: 1$ & 0,27 \\
$4: 1: 1$ & 0,28 \\
\hline
\end{tabular}

Tabel 4 menunjukkan bahwa sampel yoghurt yang dibuat pada penelitian ini memiliki kadar protein yang lebih rendah dari standar baik SNI ataupun FSANZ. Kedua standar ini menggunakan metode Kjeldahl untuk menentukan kadar protein, sedangkan pada penelitian ini digunakan metode Lowry (1951), yang hanya dapat mengukur protein terlarut. Karena kebanyakan protein yang terkandung dalam yoghurt tidak dalam bentuk protein terlarut, maka protein yang terukur pada penelitian ini menjadi lebih kecil dibandingkan standar.

Kadar protein sampel yoghurt pada penelitian ini relatif tidak terlalu berbeda antara sampel yang satu dengan yang lain dan berada pada rentang 0,23$0,30 \%(\mathrm{~b} / \mathrm{v})$. Nilai kadar protein pada yoghurt yang dibuat dengan dua kultur bakteri memiliki nilai yang relatif lebih rendah, yaitu pada rentang 0,23-0,26\% (b/v), sedangkan yoghurt yang dibuat dengan kultur tiga bakteri berada pada rentang $0,27-0,30 \%(\mathrm{~b} / \mathrm{v})$.

\section{KESIMPULAN}

Penambahan L. acidophilus pada kultur starter yoghurt yang mengandung dua bakteri (L. bulgaricus dan $S$. thermophilus) memberikan beberapa pengaruh, diantaranya yaitu meningkatkan nilai $\mathrm{pH}$, menurunkan tingkat konsumsi laktosa, menurunkan kadar asam laktat yang dihasilkan serta meningkatkan kadar protein. Hal ini dimungkinkan terjadi karena adanya interaksi antara bakteri-bakteri yang ada pada kultur starter. Penambahan $L$. acidophilus kemungkinan besar memberikan efek inhibisi terhadap kinerja dari kedua bakteri lainnya yang digunakan pada kultur starter, terutama $L$. bulgaricus.

\section{Ucapan Terima Kasih}

Kami mengucapkan terima kasih kepada U. Juharia dan Maman Tardi sebagai teknisi Laboratorium Biokimia FMIPA Unpad yang telah membantu terlaksananya penelitan ini.

\section{DAFTAR PUSTAKA}

Badan Standar Nasional. 2009. SNI 2981:2009 Yogurt.

Conway, P.L., Gorbach, S.L. \& Goldin, B.R. (1987). Survival of lactic acid bacteria in the human stomach and adhesion to intestinal cells. Journal of Dairy Science. 70: 1-12.
El-Abbassy, M.Z. \& Sitohy, M. (1993). Metabolic interaction between Streptococcus thermophilus and Lactobacillus bulgaricus in single and mixed starter yoghurt. Food / Nahrung. 37(1), 53-58.

Elli, M., Callegari, M.L., Ferrari, S., Bessi, Elena., Cattivelli, D., Soldi, S., Morelli, L., Feuillerat, N.G. \& Antoine, J.-M. (2006). Survival of yogurt bacteria in the human gut. Applied and Environmental Microbiology. 72(7), 5113-5117.

Food Standards Australia New Zealand. 2014. Standard 2.5.3 Fermented milk products.

Gardini, F., Lanciotti, R., Guerzoni, M.E. \& Torriani, S. (1999). Evaluation of aroma production and survival of Streptococcus thermophilus, Lactobacillus delbrueckii subsp. bulgaricus and Lactobacillus acidophilus in fermented milks. International Dairy Journal. 9.125-134.

Gomes, A.M.P. \& Malcata, F.X. (1999). Bifidobacterium spp. and Lactobacillus acidophilus: biological, biochemical, technological and therapeutical properties relevant for use as probiotics. Trends in Food Science \& Technology. 10, 139-157.

Lick, S., Drescher, K. \& Heller, K. (2001). Survival of Lactobacillus delbrueckii subsp. bulgaricus and Streptococcus thermophilus in the terminal ileum of fistulated Göttingen minipigs. Applied and Environmental Microbiology. 67(9), 4137-4143.

Lowry, O.H., Rosebrough, N.J., Farr, A.L. \& Randall, R.J. (1951). Protein measurement with the Folin phenol reagent. Journal of Biological Chemistry. 193: 25-275.

Mater, D.D.G., Bretigny, L., Firmesse, O., Flores, M.-J., Mogenet, A., Bresson, J.-L. \& Corthier, G. (2005). Streptococcus thermophilus and Lactobacillus delbrueckii subsp. bulgaricus survive gastrointestinal transit of healthy volunteers consuming yogurt. FEMS Microbiology Letters. 250, 185-187.

Nelson, N. (1944). A photometric adaptation of the Somogyi method for the determination of glucose. Journal of Biological Chemistry. 153: 375-380.

Rajagopal, S.N. \& Sandine, W.E. (1990). Associative growth and proteolysis of Streptococcus thermophillus and Lactobacillus bulgaricus in skim milk. Journal of Dairy Science. 73: 894 899.

Safari, A., Rachman, S.D., Kamara, D.S., Suprijana, O., Djajasoepena, S., Sutrisna, R. \& Ishmayana, S. (2016). Perbandingan kualitas yoghurt yang dibuat dengan kultur dua dan tiga bakteri. Prosiding Seminar Nasional Kimia dan Pembelajaran Kimia. Jatinangor, 12 Mei 2016.

Somogyi, M. (1952). Notes on sugar determination. Journal of Biological Chemistry. 195: 19-23.

Vinderola, C.G., Mocchiutti, P. \& Reinheimer, J. A. (2002). Interactions Among Lactic Acid Starter and Probiotic Bacteria Used for Fermented Dairy Products. Journal of Dairy Science. 85: 721-729. 